\title{
A NEW METHOD TO ESTIMATE ANNUAL AND EVENT- BASED RECHARGE COEFFICIENT IN KARST AQUIFERS; CASE STUDY: SHESHPEER KARST AQUIFER, SOUTH CENTRAL IRAN
}

\author{
Alireza Kavousi and Ezzat Raeisi
}

Dept. of Earth Sciences, College of Sciences, Shiraz University, 71454 Shiraz, Iran, kavousi@shirazu.ac.ir and e_raeisi@yahoo.com

\begin{abstract}
Quantification of recharge is a fundamental issue in evaluation and management of karst water resources. Recharge coefficient $(R C)$, which is the ratio of aquifer recharged water $(V R)$ to the total precipitation, has been widely used for recharge estimation in karst catchments. Though the $R C$ definition is straightforward, in practice, its application on a fixed short time scale (e.g., monthly or annual) is challenging, because of the problems in determination of change in groundwater storage $(\Delta V S)$ that is included in $V R$. Some researchers have neglected $\Delta V S$, estimated $V R$ as equal to the net aquifer outflows; hence they have over- or under-estimated the $R C$, ignoring the aquifer's antecedent storage condition. In this study, a new method is proposed to estimate the actual event $V R$, and consequently, the event-based $R C$, utilizing the MRC displacement method of Kavousi and Raeisi (2015). Applying the method, $V R$ due to a specific event or a combination of events during a hydrological year can be directly estimated by decomposition of the observed hydrograph to the individual hydrographs induced by different events. The method is applicable for karst aquifers with no-flow boundaries, draining by a spring. The calculated event $V R$ takes $\Delta V S$ into account, enabling an accurate event-based $R C$ estimation. The method was applied to the Sheshpeer karst aquifer in Iran. The estimated $R C s$ reasonably matched up to the catchment properties and former field studies. Results showed that the annual $R C s$ would be underestimated if the $\Delta V S$ was neglected, because $\Delta V S$ was positive during the study period.
\end{abstract}

\section{INTRODUCTION}

Recharge to karst aquifers has been widely estimated using the ratio of aquifer recharged water $(V R)$ to the total precipitation $(V P)$ over the catchment during a specific time interval, the so-called effective infiltration coefficient, EIC (Drogue, 1971; Soulios, 1984; Bonnaci, 2001):

$$
E I C=\frac{V R}{V P}
$$

Infiltration is the term used to describe the process by which water moves downward through soils and rocks (e.g., Horton, 1933). Some portion of the infiltrated water is retained as soil moisture, which may also be evapotraspirated later, not reaching the saturated zone. Therefore, the recharge amount can be a fraction of the total infiltration amount. Consequently, the term recharge coefficient, $R C$, is preferred here instead of $E I C$.

Aquifer recharged water $V R$ is the fraction of total precipitation $V P$ that reached and would be eventually discharged from the aquifer. Both $V R$ and $V P$ are expressed in $\mathrm{L}^{3}$ or just $\mathrm{L}$ averaged over the catchment; thus $R C$ is a dimensionless coefficient, theoretically ranging from 0 (when $V R=0$ ) to 1 (when $V R=V P$ ). On a global scale, the reported $R C s$ for karst aquifers cover the whole range, even approaching the two end members (see for example Ashjari and Raeisi, 2006; Allocca et al., 2014; Fiorillo et al., 2015; Martos-Rosillo et al., 2015). $R C$ simply represents the percentage of total precipitation that reached the phreatic zone, reflecting the combined effects of all rechargeprohibiting processes such as water loss through surface runoff or evapotranspiration. The ability to estimate $R C$ permits transfer of hydrological information from catchments with adequate hydrological and meteorological measurements to those with insufficient (Ford and Williams, 2007).

Given the catchment area and the spatial variation of precipitation, one can calculate the $V P$ over the catchment during a fixed time interval of a year or a month, but estimation of $V R$ is not so straightforward. The simplest method to estimate $V R$ for a karst catchment with no-flow boundaries, where all recharged water is emerging from a spring, is to consider $V R$ as equal to the net spring outflow $\left(V_{S p}\right)$ during the time interval of $V P$ estimation (see Bonnaci, 2001). Subsequently, Equation (1) is rewritten as:

$$
R C=\frac{V_{S p}}{V P}
$$

However, estimation of $V R$ by $V_{S p}$ is not accurate, because some portion of $V_{S p}$ during the $R C$ calculation interval is, in fact, released from the groundwater storage and might have had residence times of years or even decades, and some 


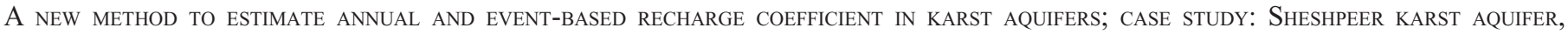
SOUTH-CENTRAL IRAN

portion of recharge water during the time interval may also remain stored in the aquifer to feed the spring afterward, so $V_{S p}$ is related to the aquifer's antecedent or subsequent storage condition, such that precipitation events of equal characteristic intensity would not always result in equal $V_{S p}$ 's; $V_{S p}$ relevant to a precipitation of $100 \mathrm{~mm}$ over a karst catchment would be different if the antecedent spring discharge level was $1 \mathrm{~m}^{3} \mathrm{~s}^{-1}$ or $10 \mathrm{~m}^{3} \mathrm{~s}^{-1}$.

For the aquifer boundary condition mentioned for the Equation (2), $V R$, and consequently $R C$, can be more accurately estimated by setting $V R$ as equal to $V_{S p}$ plus change in groundwater storage $(\Delta V S)$ during the calculation time interval (see Soulios, 1984):

$$
R C=\frac{V_{S p}+\Delta V S}{V P}
$$

$\Delta V S$ can be positive (storage replenishing) or negative (storage depleting). Equation (3) gives the exact value of $R C$ for the aforementioned aquifer boundary condition, although it suffers from the problem of $\Delta V S$ estimation in karst. The widely used water table fluctuation method for $\triangle V S$ estimation in unconfined aquifers requires specific yield and water level data at catchment scale (e.g. Rasmussen and Andreasen, 1959; Maréchal et al., 2006; Dewandel et al., 2010), which cannot be reliably determined for karst and hard rock aquifers (Healy and Cook, 2002; Raeisi, 2008).

Equation (3) is only valid for an aquifer with no-flow boundaries where the only discharge point is a spring. The more general form of $R C$ equation, considering multiple springs and wells, as well as multiple subsurface inflows and outflows, is (modified from Allocca et al., 2014):

$$
R C=\frac{\sum V_{S p}+\sum V_{W}+\sum V_{\text {Out }}+\sum V_{I n}+\Delta V S}{V P}
$$

where, $\sum V_{S p}, \sum V_{W}$ and $\sum V_{\text {Out }}$ are the net discharged water through springs, production wells, and groundwater outflows, respectively; and $\sum V_{I n}$ is the net groundwater inflows. Equation (4) is the general equation for $R C$ estimation, but it has never been used considering all its parameters. Equation (4) is shortened to Equation (3) when only one spring discharges the aquifer and $\sum V_{I n}$ and $\sum V_{O u t}$ are negligible in comparison to $V_{S p}, \Delta V S$, and $V P$. However, Equation (3) has not been commonly used either, because of the aforementioned problems in $\Delta V S$ estimations for karst aquifers. In practice, Equation (3) is further reduced to Equation (2), assuming large time scales of decades or several years for $R C$ calculation, such that the change in groundwater storage became negligible in comparison to $V_{S p}$ and $V P$. In this way, mean annual $R C\left(R C_{\bar{Y}}\right)$ is calculated (see Soulios, 1984).

$R C_{\bar{Y}}$ just provides a rough estimation of the mean annually recharged water to an aquifer on a long-term scale and is not of practical use for groundwater management. Instead, determination of $R C$ during a hydrological year, $R C_{Y}$, or even a shorter time scale (monthly $R C_{M}$ or daily $R C_{D}$ ) is of interest for practical applications (see Bonacci, 2001; Bonacci et al., 2006;
Jukić and Denić-Jukić, 2004, 2009; Jemcov and Petric, 2009; Fiorillo et al., 2015). However, at a short time scale of a year (or a month), the amount of change in groundwater storage is likely not negligible in comparison to the rest of the parameters in the $R C$ calculation. Consequently, $R C$ might be overestimated or underestimated by Equation (2) by neglecting $\Delta V S$ when $\Delta V S$ is notably negative or positive, respectively.

Bonnaci (2001) estimated the $R C_{M}$ for Gradole aquifer in Dinaric karst, during 1987 to 1998 . Using Equation (2), $R C_{M}$ of greater than 1 or even infinite was calculated for $24.3 \%$ of the cases with little or no precipitation during the month; moreover, it was believed, doubtfully, that the $R C_{J u l y}$ was higher than the $R C_{\text {June }}$. Consequently, Bonacci (2001) modified the $R C_{M}$ calculation by changing the $V_{S p}$ definition in the Equation (2). He extrapolated the recession curves during each month to the following three months using a master recession curve, MRC, of Maillet's (1905) simple exponential function. Then, $V_{S p}$ of a month was calculated as the area bounded between two successive extrapolated MRCs, up to the following three months (see Bonacci, 2001). This way, the effect of change in groundwater storage was partly covered, and some more reasonable $R C_{M}$ could have been estimated. Nevertheless, Bonacci (2001) calculated the $R C_{Y}$ using Equation (2), without any further modification to $V_{S p}$, in order to consider $\Delta V S$. The reported $R C_{Y}$ s covered a wide range of 0.356 to 0.763 .

In surface-water hydrology, MRC extrapolations are also used for groundwater recharge estimation for stream catchments. The method, so-called MRC displacement (Rorabaugh, 1964), is based on the theory of upward shifting in the streamflow recession curve as a result of recharge events (Rutledge, 1998). The procedure of the method can be summarized as follows. First, a recession curve before and after a streamflow peak is selected and extrapolated to the following time according to the stream's simple exponential MRC. Then a critical time after the peak is calculated, by which the runoff is assumed to have ceased. Finally, groundwater recharge volume is estimated as two times the area bounded between successive MRCs after the critical time (see Rorabaugh, 1964; Rutledge, 1998 for formulas and detailed explanations).

Bonacci (2001) used the simple exponential MRCs in his work that are also widely used in surface-water hydrology. The simple exponential function, known as Maillet's formula, was derived for recession curves by approximate solution of the diffusion equation in porous media (see Maillet, 1905). The formula expresses drainage from a linear reservoir and is usually used to describe the baseflow part of karst spring recession curves, but it commonly fails to match up the entire curves from high to low flow. Semi-log plots of recession curves, log discharge versus time, for many karst springs exhibit two or more linear segments with decreasing order of slopes (e.g. Torbarov, 1976; Milanović, 1976; White, 1988; Baedke and Krothe, 2001; Ford and Williams, 2007), suggesting piecewise exponential functions for the fitting. Segmentation of recession curves has been linked up with 
changes in flow regimes (Milanović, 1976; Baedke and Krothe, 2001, Doctor and Alexander, 2005; Doctor, 2008), catchment area, and effective porosity of the declining saturated zone (Bonacci, 1993; Fiorillo, 2011). MRC is here considered as a piecewise-exponential function, namely the segmented exponential MRC (Kavousi and Raeisi, 2015) composed of $n$ segments ending at times $t_{i}=1$ to $n$ with $n$ recession coefficients $\alpha_{i}=1$ to $n$, and base discharges $Q_{0(i)}=1$ to $n$, that is, exponential segment discharges at time $t=0$ for each segment.

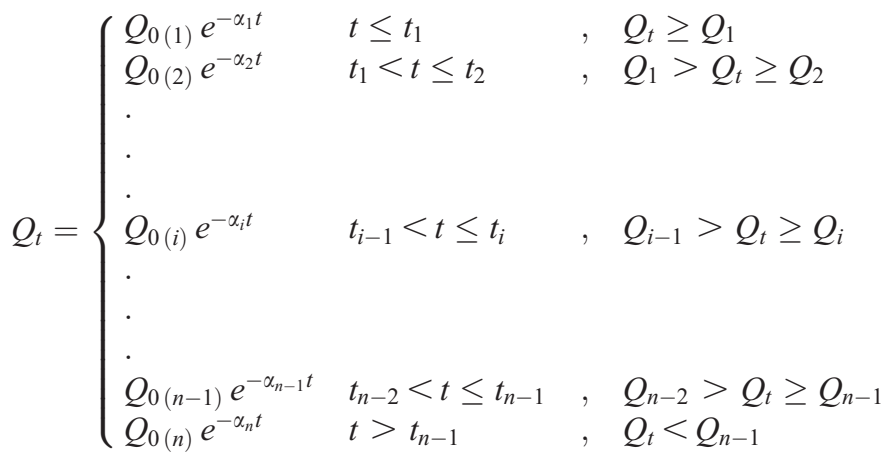

Equation (5) implies that the MRC is represented with $n$ straight lines (usually two or three) with slopes of $-\alpha_{i}=1$ to $n$ on a semi-log scale (see Figure 1a for a simple example).

In this study, a novel method is proposed to estimate $R C_{E}$ for an isolated precipitation event that induced a distinctive hydrograph rise and recession. The method is based on the hydrograph decomposition using segmented exponential MRCs (Kavousi and Raeisi, 2015) and is capable of accurate $R C_{E}$ estimation for a karst aquifer with no-flow boundaries, draining by a single spring. The only required data are the spring's long-term discharge and the spatiotemporal distribution of precipitation over the catchment.

\section{Event-Based $R C_{E}$ Estimation Method}

Recharge water from a precipitation event is stored within an unconfined karst aquifer, gradually discharging via the spring, throughout a long period during and after the event. Strictly speaking, each effective precipitation event induces a prolonged individual spring hydrograph, and the individual hydrographs overlap to make the observed spring hydrograph. Thus the observed hydrograph is regarded here as a composite hydrograph that is a combination of several consecutive individual hydrographs induced by numerous previous precipitation events.

The volume of water discharged as an individual hydrograph is, in fact, the water volume of the relevant event that entered the aquifer to be eventually discharged from the spring. Therefore, decomposition of an observed composite hydrograph to its individuals will give the recharge water volume of the individual events. Decomposition of observed composite hydrograph is here performed using the MRC (a)
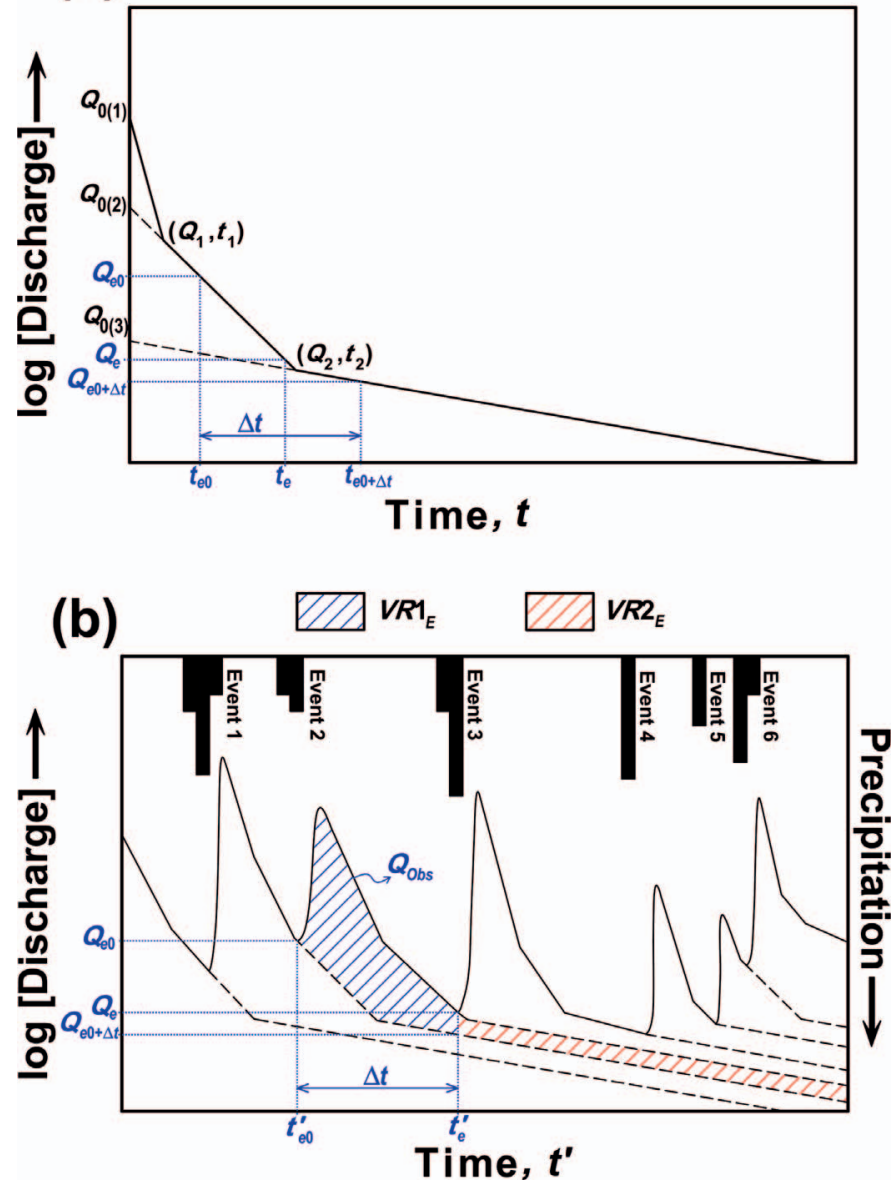

Figure 1. (a) A schematic master recession curve composed of three exponential segments, with parameters in black. (b) Hypothetical precipitation events and resulting observed hydrograph that is decomposed to individual hydrographs by extrapolations based on the MRC in (a) (dashed lines). Recharged water volume $\left(V R_{E}\right)$ for the second event is indicated with hatched areas. $V R 1_{E}$ (red hatched area) is discharged during the observed part of second individual hydrograph, but $V R 2_{E}$ (blue hatched area) is stored in the aquifer and discharged afterward, theoretically until infinite time. Parameters for the second event are specified in blue in both (a) and (b). Note that the vertical axis in both graphs is logarithmic, so that the observed hydrograph and MRCs are represented as straight lines; the base of the vertical axes is not zero.

displacement method of Kavousi and Raeisi (2015), applying the following steps:

1. The long-term composite hydrograph is measured.

2. The segmented exponential MRC of the spring is constructed using all prior recorded recessions, from high- to low-flows (see Figure 1a).

Journal of Cave and Karst Studies, December 2016 165 


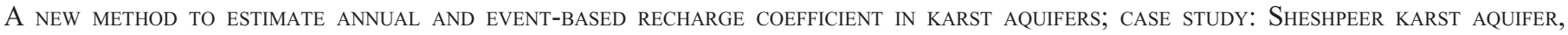
SOUTH-CENTRAL IRAN

3. The observed composite hydrograph is decomposed to its individuals by extrapolation of recession curves, by means of the MRC. For this reason, the MRC is horizontally displaced at the end of composite hydrograph recessions (see Kavousi and Raeisi, 2015). Figure 1b shows a hypothetical composite hydrograph that is decomposed to its individuals corresponding to different precipitation events, using the segmented exponential MRC presented as Figure 1a.

4. The event's recharged water volume $V R_{E}$ is the area bounded by the relevant individual hydrograph, that is calculated by integration, as follows (see Figure 1b):

$$
\begin{aligned}
V R_{E}= & \left(\int_{t_{e 0}^{\prime}}^{t_{e}^{\prime}} Q_{O b s} d t^{\prime}-\int_{t_{e 0}}^{t_{e 0}+\Delta t} Q_{t} d t\right) \\
& +\left(\int_{t_{e}}^{\infty} Q_{t} d t-\int_{t_{e 0}+\Delta t}^{\infty} Q_{t} d t\right)
\end{aligned}
$$

where, $t$ and $t^{\prime}$ are the time-scales for the MRC and measured hydrograph; $t_{e 0}^{\prime}$ and $t_{e}^{\prime}$ are the times of rise beginning and recession ending on the observed part of the individual hydrograph, respectively; $Q_{O b s}$ and $Q_{t}$ are the observed discharge and MRC discharge at time $t$, respectively; $t_{e 0}$ and $t_{e}$ are the MRC-equivalent times for the observed discharges $Q_{e 0}$ (at time $t_{e}^{\prime}$ ) and $Q_{e}$ (at time $t_{e 0}^{\prime}$ ), respectively; and $\Delta t$ is the time difference between $t_{e}^{\prime}$ and $t_{e 0}^{\prime}\left(\right.$ or $t_{e}$ and $t_{e 0}$ ). Figure 1 graphically presents $V R_{E}$ and the abovementioned parameters on a schematic hydrograph and MRC.

$V R_{E}$ is the fraction of total precipitation over the catchment that entered the aquifer and is eventually discharged from the spring. Some portion of this water volume was discharged during the observed part of individual hydrograph $\left(V R 1_{E}\right.$, the blue hatched area in Figure 1b), but some extrapolated portion would be gradually discharged later $\left(V R 2_{E}\right.$, that is indicated as the red hatched area in Figure 1b). The two terms of Equation (6) are $V R 1_{E}$ and $V R 2_{E}$, respectively.

Providing $V R_{E}$, recharge coefficient of the event $\left(R C_{E}\right)$ can be estimated for an aquifer with no-flow boundaries draining by a permanent spring, Equation (1) becomes

$$
R C_{E}=\frac{V R_{E}}{V P_{E}}=\frac{V R 1_{E}+V R 2_{E}}{V P_{E}}
$$

where $V P_{E}$ is the estimated volume of total precipitation over the catchment during the event. The no-flow boundaries may coincide with impermeable layers or groundwater divides. Lots of karst aquifers in the Zagros Mountain Range, and also in other karst regions worldwide, meet the condition.

Equation (7) estimates $R C_{E}$ of an isolated precipitation event that induced a single distinct hydrograph rise followed by a peak and a recession. However, $R C_{E}$ for a combination of precipitation events can also be estimated by combining individual hydrographs and precipitation events, treating all of them as a single event, so in case some individual hydrographs or precipitation events are indistinguishable, one would be able to calculate the $R C_{E}$ of the overall collection of events. This is likely to be the case when the precipitation is mostly snow or the time intervals between rainy periods are short. By combining individual hydrographs for precipitation events during a hydrological year, accurate estimation of $R C_{Y}$ would also be possible.

Equation (6) can be rearranged to give

$$
V R_{E}=(\underbrace{\int_{t_{e 0}^{\prime}}^{t_{e}^{\prime}} Q_{O b s} d t^{\prime}}_{V_{E}})+(\underbrace{\int_{t_{e}}^{\infty} Q_{t} d t}_{V S_{E}}-\underbrace{\int_{t_{e 0}}^{\infty} Q_{t} d t}_{V S 0_{E}})
$$

where, $V_{E}$ is the net spring outflow during the measured part of the individual hydrograph, and $V S_{0 E}$ and $V S_{E}$ are the dynamic reservoir volumes (see Burdon and Papakis, 1963; Ford and Williams, 2007, p. 179) at the beginning and end of the measured part of the hydrograph, respectively. $V S_{E}$ and $V S 0_{E}$ can be calculated by the following equations, replacing $Q_{t}$ with the MRC Equation (5):

$$
\begin{aligned}
V S_{E}=\int_{t_{e}}^{\infty} Q_{t} d t \Rightarrow V S_{E}= \begin{cases}C\left(\frac{Q_{e}-Q_{i}}{\alpha_{i}}+\frac{Q_{i}-Q_{i+1}}{\alpha_{i+1}}+\cdots+\frac{Q_{n-2}-Q_{n-1}}{\alpha_{n-1}}+\frac{Q_{n-1}}{\alpha_{n}}\right) & Q_{e}>Q_{n-1} \\
C\left(\frac{Q_{e}}{\alpha_{n}}\right) & Q_{e}<Q_{n-1}\end{cases} \\
V S 0_{E}=\int_{t_{e 0}}^{\infty} Q_{t} d t \Rightarrow V S 0_{E}= \begin{cases}C\left(\frac{Q_{e 0}-Q_{i}}{\alpha_{i}}+\frac{Q_{i}-Q_{i+1}}{\alpha_{i+1}}+\cdots+\frac{Q_{n-2}-Q_{n-1}}{\alpha_{n-1}}+\frac{Q_{n-1}}{\alpha_{n}}\right) & Q_{e 0}>Q_{n-1} \\
C\left(\frac{Q_{e 0}}{\alpha_{n}}\right) & Q_{e 0}<Q_{n-1}\end{cases}
\end{aligned}
$$


where, $C$ is the unit conversion factor, equal to 86400 when discharge and recession coefficient units are $\mathrm{m}^{3} \cdot \mathrm{s}^{-1}$ and $\mathrm{d}^{-1}$, respectively.

The second term in the right side of Equation (8) is the difference between $V S_{E}$ and $V S 0_{E}$, that is the change in groundwater storage due to the event $\left(\Delta V S_{E}\right)$, according to Raeisi (2008)

$$
\Delta V S_{E}=V S_{E}-V S 0_{E}
$$

$\Delta V S_{E}$ would be positive, if the baseflow discharge level at the beginning of measured part of individual hydrograph is higher at its end, or negative if lower.

Considering Equations (8) and (11), Equation (7) can be written as

$$
R C_{E}=\frac{V_{E}+\Delta V S_{E}}{V P_{E}}
$$

Equation (7) is essentially Equation (3) adapted for an event. Thus the proposed method estimates the $R C$ in a short interval of an event $R C_{\mathrm{E}}$, taking change in groundwater storage into account. Ignorance of a positive or negative $\Delta V S$ in an $R C_{\mathrm{E}}$ calculation causes under- or over-estimation.

\section{Application: Sheshreer Karst Aquifer, Iran}

To examine the proposed method of $R C_{E}$ estimation, Sheshpeer karst aquifer, located in the Zagros Mountain Range, $80 \mathrm{~km}$ northwest of Shiraz, south-central Iran, was used as a case study. The Zagros orogenic belt is comprised of three parallel northeast-southwest trending tectonic subdivisions, the Urumieh-Dokhtar Magmatic Assemblage, the Zagros Imbricate Zone, and the Zagros Fold-Thrust Belt (Alavi, 2007). Lithostratigraphic units and tectonic settings of these subdivisions are fairly well described by James and Wynd (1965), Falcon (1974), Stöcklin and Setudehnia (1971), and Alavi (1994, 2007). The Sheshpeer karst aquifer is situated at the border of the Zagros Fold-Thrust Belt and the Imbricate Zone. Extensive studies, including hydrology (Azizi, 1992; Porhemat, 1993), hydrogeology (Pezeshkpour, 1991; Karami, 1993; Raeisi et al. 1993, 1999; Eftekhari, 1994; Raeisi and Karami, 1996; Kavousi, 2008; Raeisi, 2008, 2010; Kavousi and Raeisi, 2015), geomorphology (Kasaeyan, 1990; Marandi, 1990), structural geology (Agha-Amiri, 1993), geophysics (Nakhaei, 1992) and remote sensing (Ebadian, 2002) were carried out on the Sheshpeer catchment.

\section{Hydrogeological Setting}

The Sheshpeer aquifer is composed of the calcareous Sarvak Formation (Albian-Turonian) in the northern flank of the Barm-Firooz and Gar anticlines and a portion of the BarmFirooz anticline southern flank (Raeisi et al., 1993; Raeisi, 2008; Fig. 2). The anticlines are extended in the general direction of the Zagros Mountain Range and are connected by a saddle-shaped plunge. The exposed cores of the anticlines are mainly composed of the karstic Sarvak Formation,

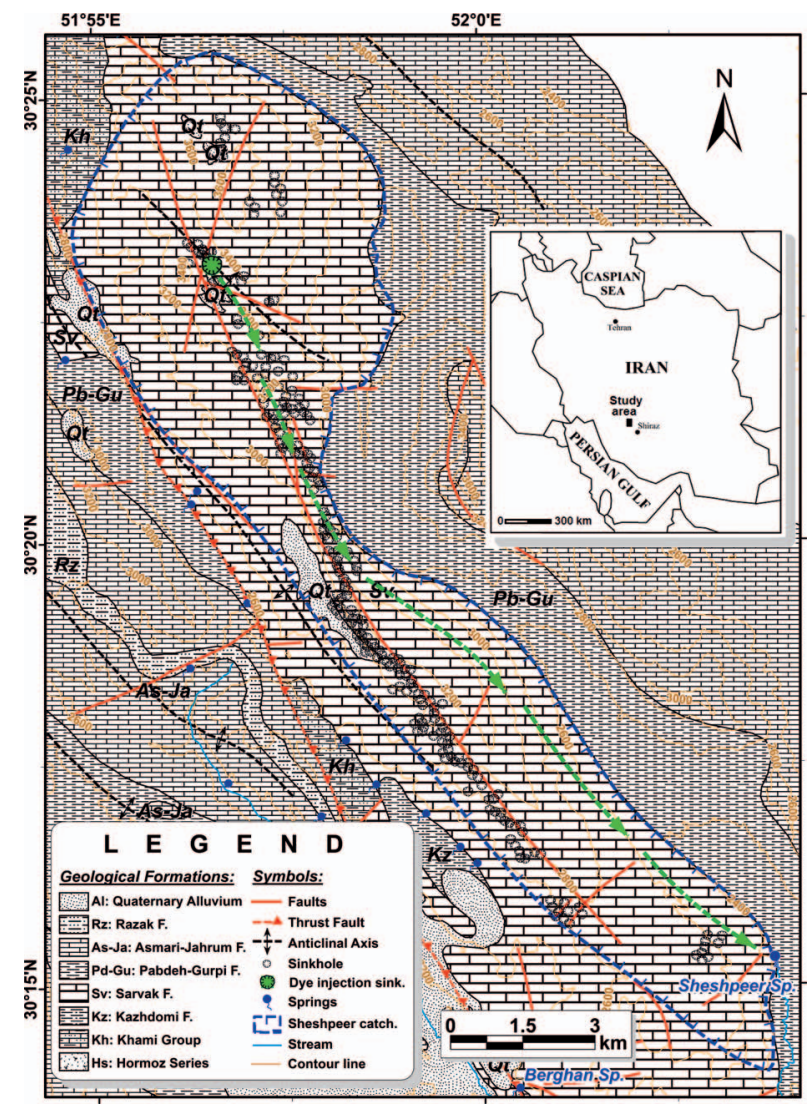

Figure 2. Hydrogeological map of the study area. The green arrows represent the most likely flow path from the dye-injection sinkhole to the spring. The catchment area for the Sheshpeer Spring is outlined in blue.

underlain and overlain by impermeable shale and marl layers of the Kazhdomi (Albian-Cenemonian) and Pabdeh-Gurpi (Santonian-Oligocene) Formations, respectively.

The most important tectonic feature is a major northwestsoutheast trending thrust fault (Fig. 2). The northern flank of the anticlines has been brought up by tectonic stresses, and the southern flank has been brecciated so that it is either completely removed or crops out as large rockslide blocks. Several normal and strike-slip faults are also present. The overall tectonic setting of the area has produced suitable conditions for extensive karstification (Raeisi and Karami, 1996, 1997; Raeisi, 2010).

The karst features of the study area are grikes, karrens, small caves, sinkholes, and springs. The most important karst feature is the presence of 259 sinkholes in the Gar and BarmFirooz Mountains, aligned in a narrow zone on top of the northern flanks from the northern end of the catchment to near of the Sheshpeer Spring (Fig. 2). The sinkholes are primarily of the collapse-doline type and evidently aligned along the strike direction of longitudinal faults. The biggest cave in the catchment has a length of $20 \mathrm{~m}$ and is located along a fracture (Raeisi, 2010). Out of twelve springs emerging from the Sarvak Formation in the Gar and Barm-Firooz anticlines, only 


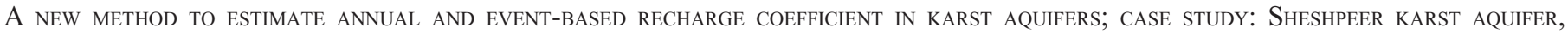
SOUTH-CENTRAL IRAN

Sheshpeer Spring, with a mean annual discharge of 3247 L $\mathrm{s}^{-1}$, is located on the northern flanks (Fig. 2). Berghan Spring is the largest spring in the southern flanks and has a mean annual discharge of $632 \mathrm{~L} \mathrm{~s}^{-1}$. The mean annual discharges for the rest of the springs range from 1.41 to $68.34 \mathrm{~L} \mathrm{~s}^{-1}$ (Raeisi and Karami, 1996). The outlet level of the Sheshpeer and Berghan Springs are 2335 and 2145 masl, respectively.

All boundaries of the Sheshpeer aquifer are physically noflow, and all recharged water only emerges via the Sheshpeer Spring (Pezeshkpour, 1991). Groundwater balance indicates a catchment area of about $81 \mathrm{~km}^{2}$ for the Sheshpeer Spring (Raeisi et al., 1993).The catchment area is in accordance with the area bounded by geological formations, and has a mean ground elevation of 2998 masl. The aquifer boundaries are based on the following observations (Raeisi, 2008): (1) The northern flank of the Gar and Barm-Firooz anticlines have been brought up by tectonic stresses, such that the aquifers of the northern and southern flanks have been disconnected by the underlying impermeable Khazdumi Formation that crops out in some portions of the anticline core (Fig. 2). Tracer tests have confirmed this hydrogeological disconnection. (2) The northwest and northeast boundaries of the catchment are surrounded by the impermeable Pabdeh-Gurpi Formations.

Groundwater flow through the Sarvak Formation under these formations is not possible, because karstification is not expected to occur under an $800 \mathrm{~m}$ thick layer of the Pabdeh-Gurpi Formations, there are no outcrops of the Sarvak Formation in adjacent parallel anticlines, and tracer tests confirmed the hydrogeological disconnection with the springs of the adjacent anticlines. (3) Sinkholes are only located in the catchment of Sheshpeer Spring, and the uranine tracer injected in a sinkhole $18 \mathrm{~km}$ away only emerged from this spring.

\section{Hydrological Data}

The hydrograph of the Sheshpeer Spring was measured for almost three hydrological years from 1990-1991 to 1992-1993 (Pezeshkpour, 1991; Karami, 1993; Eftekhari, 1994). Kavousi and Raeisi (2015) reconstructed ten years of daily discharge data for the spring by means of a multiple time-series regression model (Phillips and Durlauf, 1986) based on the recorded discharge at two hydrometric stations downstream of the spring and also the precipitation at a climatological station. The segmented exponential MRC determined for the spring based on the thirteen-year hydrograph is (Kavousi and Raeisi, 2015)

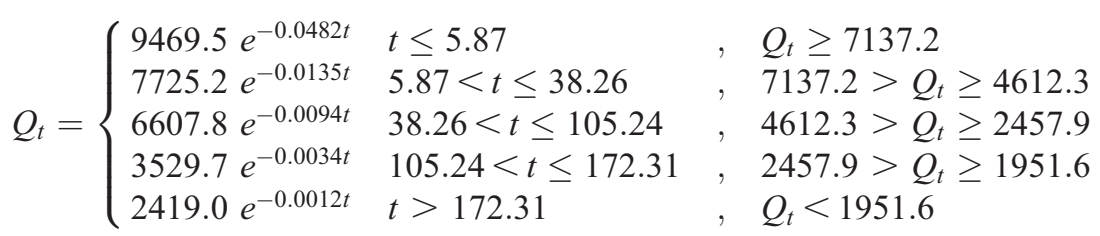

where the units of discharge, recession coefficient, and time are $\mathrm{L} \mathrm{s}^{-1}, \mathrm{~d}^{-1}$, and $\mathrm{d}$, respectively.

The climate type of the study area is Mediterranean, characterized by mild, dry summers and cool, wet winters. Precipitation events are normally isolated, occurring during late fall, winter, and early spring. There is no precipitation during the rest of the year. The precipitation in winter is mainly in the form of snow.

To estimate spatial distribution of precipitation over the Sheshpeer catchment, ten precipitation-gauge stations were selected. Stations were selected based on their availability and locations parallel to the northwest-southeast general direction of Zagros Mountain Range and also Mediterranean frontal systems, which are the main source of precipitation in the region (see Sabziparvar et al., 2015). Figure 3 shows the spatial distribution of the stations on a Triangular Irregular Network map that highlights the topographical features. Preliminary studies indicated that the short-term precipitation timing and amount at stations far in the northeast and southwest of the Sheshpeer catchment, perpendicular to the general direction of Zagros and also Mediterranean frontal systems, are not similar to those of the stations close to the catchment. Therefore, stations far in the northeast and southwest of the Sheshpeer catchment were not considered, since they are not representative for the catchment precipitations. Alijani (2008) proved that the Zagros Mountains block the moist air masses from entering central Iran to the northeast and east.

Shekarak station, which is located on the Barm-Firooz southern flank in the vicinity of the Sheshpeer catchment, was installed by Shiraz University to measure climatological parameters and facilitate water-balance calculations. Although the station is the most representative for the Sheshpeer catchment, it was only active during hydrological year 1991-1992. Precipitation data at the Komehr and Sepidan stations were also not available during 1991 to 1993, and thus, were reconstructed based on the data from adjacent Chubkhale and Berghan stations. The linear correlation coefficients of precipitation amounts for Komehr with Chubkhale and Sepidan with Berghan stations were 0.93 and 0.98 , respectively. These are very close to 1 , showing the accuracy available for reconstructing the missing data.

\section{Results AND Discussions}

The proposed method is able to estimate a recharge coefficient $R C_{E}$ for an isolated precipitation event that induced a distinctive hydrograph rise and recession and also for a 


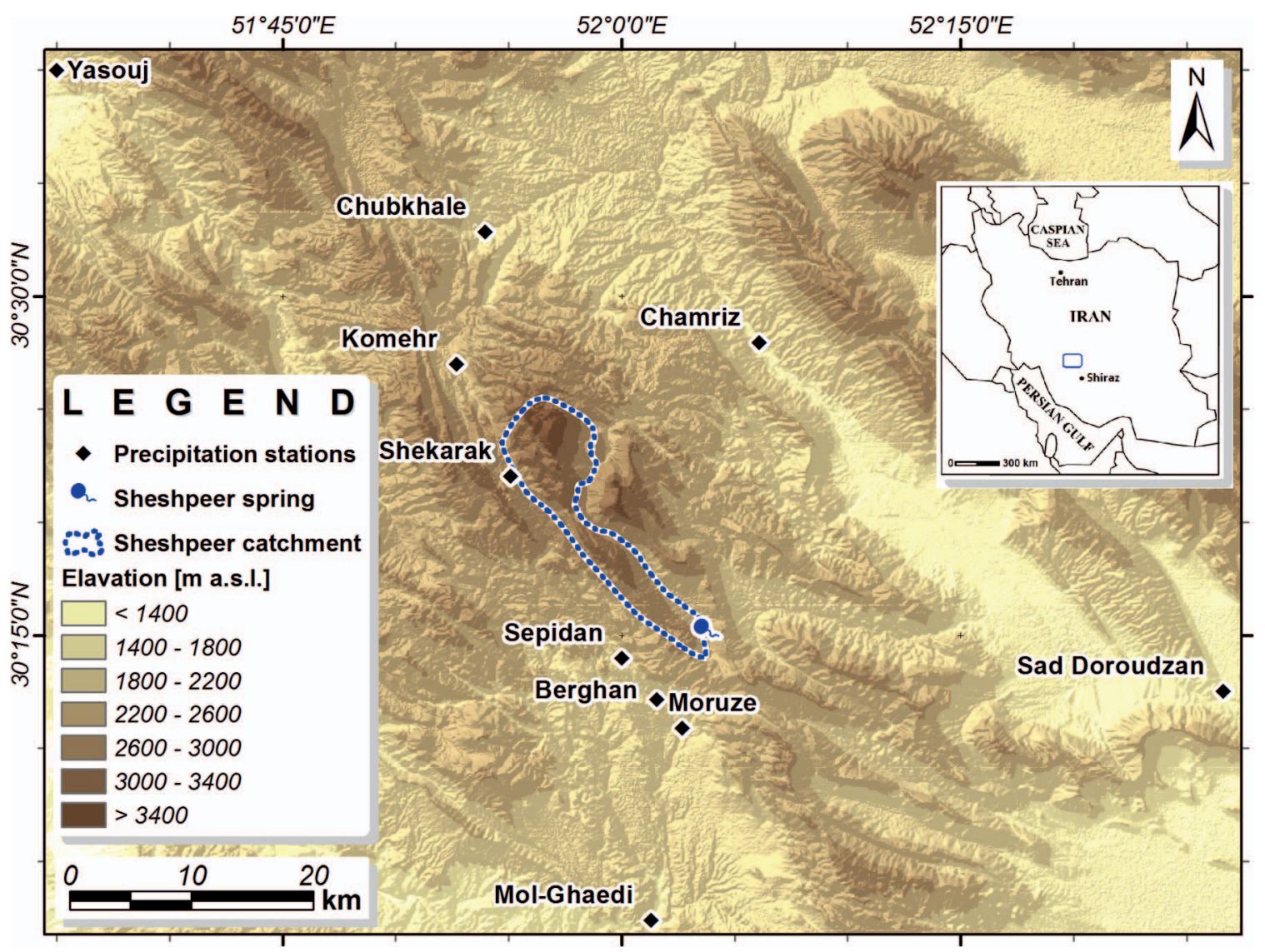

Figure 3. Spatial distribution of precipitation gauge stations on the TIN map. Sheshpeer Spring and its catchment are indicated.

combination of precipitation events such as $R C_{Y}$ for a hydrological year. For the Sheshpeer catchment, two $R C_{Y}$ and nine $R C_{E}$ can be calculated.

Sheshpeer aquifer has a single spring and all its boundaries are no-flow. Measured spring discharge comprises hydrographs of two hydrological years 1990-1991 and 1991-1992 and some part of the hydrological year 1992-1993. Therefore $R C_{Y}$ can be calculated just for hydrological years 1990-1991 and 1991-1992. But the overall hydrograph can be decomposed to nine individual hydrographs by means of Equation (13), the spring's segmented exponential MRC (see Fig. 4). It should be pointed out that the first individual hydrograph of the hydrological year 1992-1993 (92-93-1 in the figure) consisted of some spring discharge with indistinguishable precipitation events; therefore, the overall precipitation during the series of events is treated as the $V P_{E}$, and the overall minor peaks are treated like a single individual hydrograph in the $V R_{E}$ calculations.

Cumulative precipitation amount corresponding to each individual hydrograph or hydrological year was determined at all gauging stations and was used to estimate the total precipitation over the catchment. Multilinear-regression models were used to estimate the spatial distribution of precipitation over the catchment. The MLR models have previously been used for mountainous regions (e.g., Marquínez et al., 2003; Naoum and Tsanis, 2004; Um et al., 2010). Cumulative precipitation $P$ and geographical position altitude $Z$, latitude $X$, and longitude $Y$ of the stations were used as response and predictor variables, respectively. Different alternative MLR models were examined by stepwise regression to find the statistically most robust model. The best MLR models for the second event of hydrological year 1991-1992, all events of hydrological year 1992-1993, and the long-term period of 1972 to 2012, utilize $Z$ and $Y, Z$ only, and $Z$ and $X$, respectively, while the best MLR models for the rest are dependent on all three predictors. Table 1 presents the MLR models for the events, the hydrological years, and also the long-term mean from 1972 to 2012 . Adjusted $R^{2}$, which is an indicator of explanatory power of models, is above 0.7 for all the MLR models, except for two events in the hydrological year 1992-1993.

Spatial distribution of precipitation over the catchment was calculated with GIS, using the corresponding MLR model and the digital elevation model of the region. The calculated mean precipitations over the catchment, $P_{\text {Mean }}$, are also listed in Table 1. Figure 5 shows the spatial distribution of mean annual precipitation over the catchment for the long-term period of 1972 to 2012. The minimum, mean, and maximum

Journal of Cave and Karst Studies, December 2016 • 169 


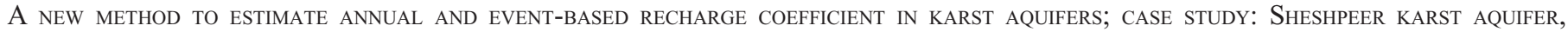
SOUTH-CENTRAL IRAN

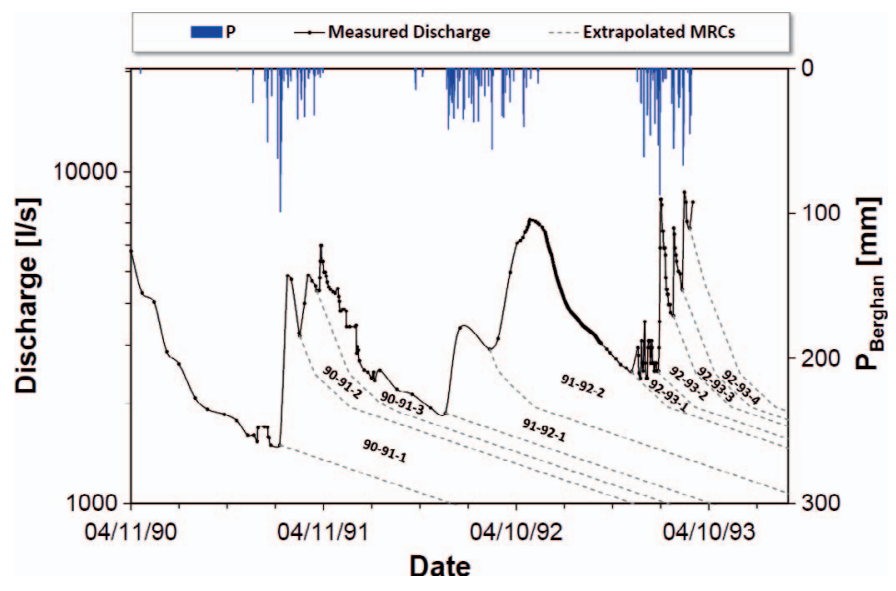

Figure 4. Sheshpeer Spring hydrograph and the corresponding precipitation hyetograph at the Berghan station. Extrapolated master recession curves (dashed lines) are appended at the end of observed recessions, decomposing the measured hydrograph into components. The number of the individual event hydrograph for each hydrological year is indicated; for example, 91-92-2 is the second individual hydrograph during hydrological year 1991-1992; these numbers are used in Table 1 and Figure 6. Note that the vertical axis for discharge is logarithmic.

precipitation over the catchment for this period of years are $887.6,1256.3$, and $1628.7 \mathrm{~mm} \mathrm{y}^{-1}$, respectively. It should be pointed out that the MLR model of long-term precipitation has not been used for the $R C$ calculations in this study, but is just given to provide a sense of precipitation distribution over the catchment, which is highly dependent on its mountainous landscape.

The amount of $V_{\mathrm{Sp}}, V S, V S 0, \Delta V S, V R 1, V R 2$, and $V R$ for the hydrological years and also the nine events were calculated using Equations (6) and (8) to (11) and are shown in Table 2. The changes in groundwater storage for all the hydrological years and events are positive, except for the third and second events of the hydrological years 1990-1991 and 1991-1992, respectively. VP over the Sheshpeer catchment are also computed by GIS (Table 2). Finally, $R C$ of the events and hydrological years were estimated using Equations (7) or (12) and are shown in the Table 2 and Figure 6.

The calculated $R C_{E}$ has a wide range of variation, and the $R C_{E}$ for the last event of each hydrological year is larger than the preceding $R C_{E}$ during the same year. $R C_{91-92-2}$ even goes slightly beyond the feasible range to 1.08 . $R C_{E}$ for the hydrological year 1992-1993 are also smaller than those of former hydrological years. The fact that the Sheshpeer catchment is mountainous and most of the precipitation is snow is most likely the main reason for this behavior. Porhemat and Raeisi (2001) reported that about $65 \%$ of the total precipitations was snow in hydrological year 1991-1992. Field observations show that snowmelt happens on the peak of Gar and Barm-Firooz Mountains even in May-June. Therefore, some portion of snowpack from initial events in a hydrological year could melt and recharge the aquifer during the following events' period. So, according to Equation (7), the $R C_{E}$ is underestimated for early snowfall events, since the $V P_{E}$ is overestimated, as all equivalent water of early snow precipitation does not enter the aquifer during the event. This phenomenon is the main reason for $R C_{E}$ underestimation for early snowfall events, as well as $R C_{E}$ overestimation for the subsequent events. On other hand, the antecedent moisture condition was definitely lower for the initial events of each hydrological year, requiring some precipitation water to compensate for the soil-moisture deficit, which in turn reduces the $V R_{E}$ and $R C_{E}$ for the initial events of each year. Consequently, the calculated $R C_{Y} \mathrm{~s}$ can be considered as more accurate than $R C_{E} \mathrm{~S}$ for our case study.

Porhemat (1993) directly measured runoff and snow storage and estimated snow melt and sublimation by regionally calibrated equations in three small catchments near the Shekarak station, near the Sheshpeer catchment (see Fig.

Table 1. Calculated multilinear-regression models for the events, hydrological years, and long-term average, together with the adjusted $\boldsymbol{R}^{2}$ for the fit and the resulting mean precipitation over the Sheshpeer catchment.

Hydrological

Year

Event/Period

Regression Formula

Catchment

$90-91$

1
2

3

$91-92$

Overall

1

2

Overall

$92-93$

1

2

3

4

$1972-2012$

41 years

$$
\begin{aligned}
& P_{90-91-1}=21368+0.45455 Z-359.3 X-105.0 Y \\
& P_{90-91-2}=786+0.210704 Z-95.21 X+128.52 Y \\
& P_{90-91-3}=-4989+0.17508 Z-34.07 X+215.26 Y \\
& P_{90-91}=17165+0.8404 Z-488.6 X+238.7 Y \\
& P_{91-92-1}=6136+0.34067 Z-258.4 X+232.8 Y \\
& P_{91-92-2}=-13740+0.52921 Z+436.6 Y \\
& P_{91-92}=-3488+0.8627 Z-315.1 X+631.4 Y \\
& P_{92-93-1}=-105.66+0.13546 Z \\
& P_{92-93-2}=-157.33+0.23976 Z \\
& P_{92-93-3}=-114.28+0.12462 Z \\
& P_{92-93-4}=-191.36+0.20766 Z \\
& P_{1972-2012}=17030+0.5215 Z-333.7 X
\end{aligned}
$$

$P_{\text {Mean }}, \mathrm{mm}$

$\begin{array}{rr}89.5 & 876.3 \\ 92.6 & 371.3 \\ 94.7 & 298.5 \\ 93.3 & 1542.8 \\ 79.6 & 794.6 \\ 89.6 & 1091.9 \\ 86.0 & 1889.5 \\ 69.6 & 302.4 \\ 75.9 & 564.9 \\ 66.2 & 261.1 \\ 78.5 & 434.2 \\ 79.6 & 1256.3\end{array}$




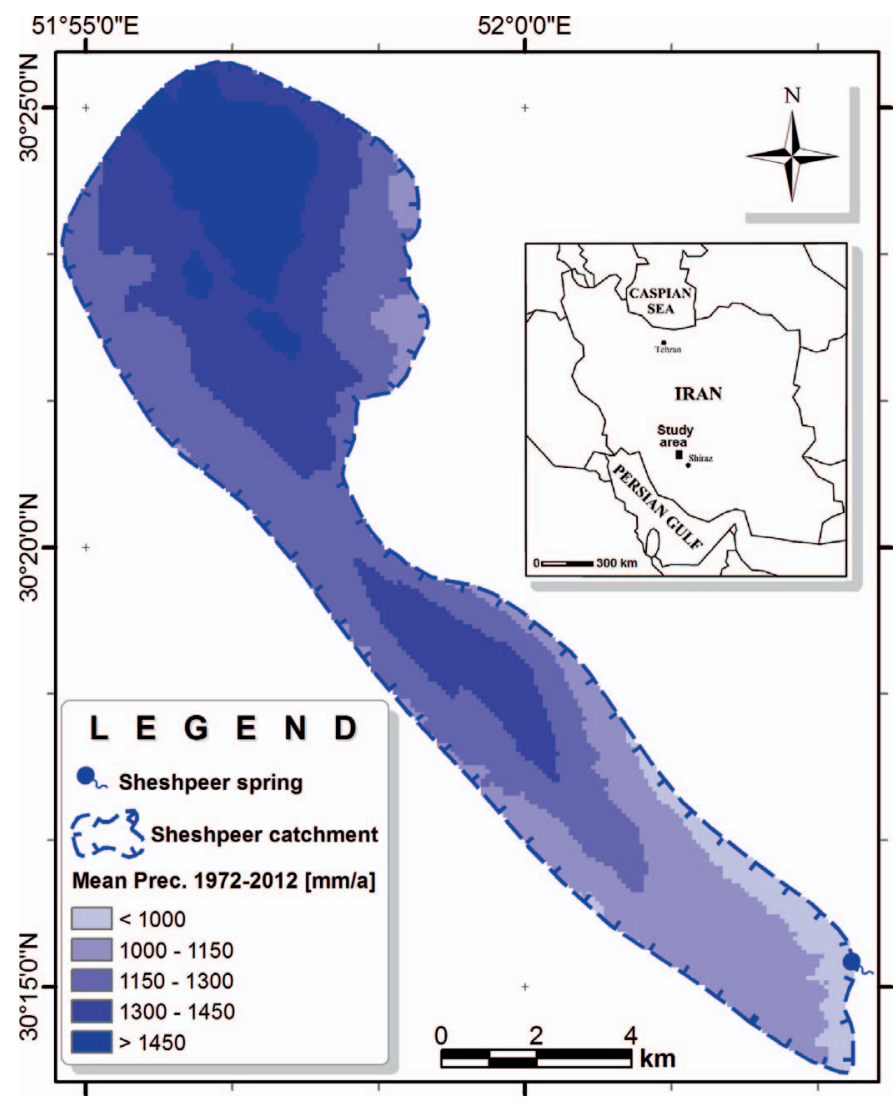

Figure 5. Spatial distribution of mean annual precipitation over the Sheshpeer catchment during 1972 to 2012 based on multilinear regression from precipitation gauges in the vicinity of the catchment.

3). The average sublimation, runoff, and recharge from snowmelt for the selected catchments during hydrological year 1991-1992 were estimated to be 5.2, 25.3, and 69.5 percent, respectively. Porhemat stressed that in the Sheshpeer catchment, which is covered by 259 sinkholes, the $R C$ could

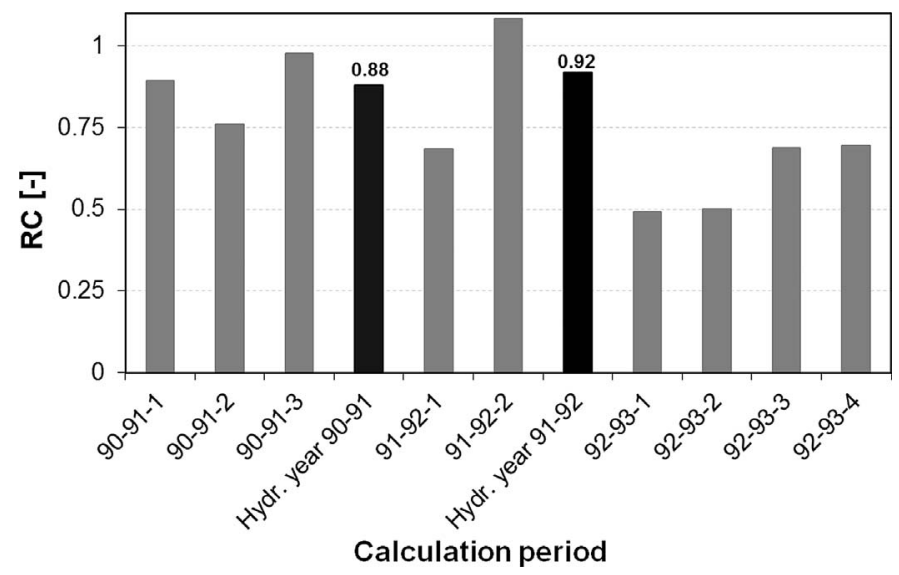

Figure 6. Estimated recharge coefficient $R C_{\mathrm{E}}$ for events (gray bars) and hydrological years $R C_{Y}$ (black bars) for the Sheshpeer aquifer during hydrological years 1990-1991 to 1992-1993.

be as high as $\sim 95 \%$, so that almost all the snow contributed direct recharge. The estimated $R C_{Y}$ s for the 1990-1991 and 1991-1992 years found in the current study are 88 and 92 percent, respectively, which are very close to the estimated value by Porhemat. The small discrepancy can be caused by several things. The multilinear-regression model we used might have incorrectly estimated the precipitation. The $R C_{Y}$ in the current study accounts for all the processes that prevented precipitation from reaching the saturated zone. Porhemat considered sublimation as the only alternative to recharge in the catchment during snow-melting. Although recharge of the Sheshpeer aquifer is limited to a 5 or 6 month wet season, the catchment is a natural pasture (Raeisi and Karami, 1996) and almost $35 \%$ of the karstic Sarvak Formation is covered by soil (Karami, 1993). Therefore evapotranspiration might account for some water loss, especially during growing season. Spring discharge was measured weekly or even monthly in some periods, especially during baseflow, which might have

Table 2. Estimated $R C$ for events $\left(R C_{\mathrm{E}}\right)$ and hydrological years $\left(R C_{\mathrm{Y}}\right)$ calculated in this study. For the definitions of the parameters entering into the result, see the text. $R C^{*}{ }_{Y}$ is the annual $R C_{Y}$ calculated neglecting $\Delta V S_{Y}$.

\begin{tabular}{|c|c|c|c|c|c|c|c|c|c|c|c|c|}
\hline Year & Event & Duration & $\begin{array}{c}V S, \\
\mathrm{Mm}^{3}\end{array}$ & $\begin{array}{l}V S 0 \\
\mathrm{Mm}^{3}\end{array}$ & $\begin{array}{l}\Delta V S \\
\mathrm{Mm}^{3}\end{array}$ & $\begin{array}{c}V_{S p} \\
\mathrm{Mm}^{3}\end{array}$ & $\begin{array}{l}V R 1 \\
\mathrm{Mm}^{3}\end{array}$ & $\begin{array}{l}V R 2, \\
\mathrm{Mm}^{3}\end{array}$ & $\begin{array}{l}V R, \\
\mathrm{Mm}^{3}\end{array}$ & $\begin{array}{c}V P \\
\mathrm{Mm}^{3}\end{array}$ & $R C$ & $R C_{Y}^{*}$ \\
\hline \multirow[t]{4}{*}{$90-91$} & 1 & $12 / 21 / 1990-02 / 19 / 1991$ & 154.9 & 104.0 & 50.9 & 12.5 & 7.7 & 55.7 & 63.3 & 71.0 & 0.89 & $\ldots$ \\
\hline & 2 & $02 / 20 / 1991-03 / 22 / 1991$ & 165.7 & 154.9 & 10.9 & 11.9 & 4.3 & 18.5 & 22.8 & 30.1 & 0.76 & $\ldots$ \\
\hline & 3 & 03/23/1991 - 11/30/1991 & 129.7 & 165.7 & -36.0 & 59.6 & 11.0 & 12.5 & 23.6 & 24.2 & 0.98 & $\ldots$ \\
\hline & $\cdots$ & Hydrologic year & 450.3 & 424.6 & 25.7 & 84.0 & 23.0 & 86.7 & 109.7 & 125.0 & 0.88 & 0.67 \\
\hline \multirow[t]{3}{*}{$91-92$} & 1 & $12 / 1 / 1991-01 / 11 / 1992$ & 152.3 & 129.7 & 22.5 & 21.6 & 8.7 & 35.4 & 44.1 & 64.4 & 0.69 & $\cdots$ \\
\hline & 2 & $01 / 12 / 1992-11 / 14 / 1992$ & 148.4 & 152.3 & -3.9 & 100.3 & 55.7 & 40.7 & 96.5 & 89.1 & 1.08 & $\cdots$ \\
\hline & $\ldots$ & Hydrologic year & 300.6 & 282.0 & 18.6 & 121.9 & 64.4 & 76.1 & 140.6 & 153.1 & 0.92 & 0.80 \\
\hline \multirow[t]{4}{*}{$92-93$} & 1 & $11 / 15 / 1992-12 / 20 / 1992$ & 148.5 & 148.4 & 0.1 & 12.0 & 2.0 & 10.1 & 12.0 & 24.5 & 0.49 & $\cdots$ \\
\hline & 2 & $12 / 21 / 1992-01 / 30 / 1993$ & 159.3 & 148.5 & 10.8 & 12.1 & 6.4 & 16.5 & 22.9 & 45.8 & 0.50 & $\cdots$ \\
\hline & 3 & $01 / 31 / 1993-02 / 18 / 1993$ & 166.1 & 159.3 & 6.8 & 7.7 & 2.7 & 11.8 & 14.5 & 21.1 & 0.69 & $\cdots$ \\
\hline & 4 & $02 / 19 / 1993-03 / 04 / 1993$ & 181.7 & 166.1 & 15.7 & 8.7 & 3.7 & 20.7 & 24.4 & 35.2 & 0.69 & $\cdots$ \\
\hline
\end{tabular}




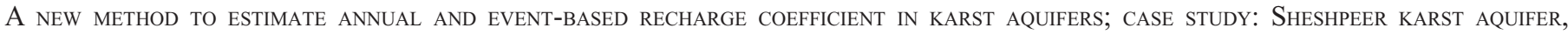
SOUTH-CENTRAL IRAN

reduced the accuracy of $V_{S p}$ and consequently $R C$ in the current study.

The effect of ignoring change in groundwater storage in the $R C$ calculations was also investigated. $R C_{Y}^{*}$ in Table 2 is $R C_{Y}$ neglecting change in groundwater storage, that is, considering $\Delta V S_{Y}=0$. Ignoring $\Delta V S_{Y}$ causes $R C^{*}{ }_{Y}$ to be less than $R C_{Y}$; the fact that the $\Delta V S_{Y}$ is positive for both hydrological years is the reason for this result. $R C^{*}{ }_{Y}$ would be greater than $R C_{Y}$ if $\Delta V S_{Y}$ was negative.

\section{Conclusions}

Knowledge of recharge coefficient $R C$ during a hydrological year or a shorter time scale is of central importance in karst water evaluation and exploitation studies. Determination of the change in groundwater storage $\Delta V S$ is a prerequisite for a reliable estimation of $R C$ on short time scales, especially in case $\Delta V S$ is significant in comparison to the other parameters in the $R C$ equation. A new method is proposed to estimate event-based $R C$ s for a single or a combination of precipitation events with distinctive hydrograph spikes. The basis of the method is decomposition of the measured hydrograph to its individual components by displacement of a segmented exponential master recession curve to the end of recession curves. The method is applicable for karst aquifers with noflow boundaries draining by a permanent spring, where the overflow and underflow components are absent or negligible.

It was proved that the estimated event-based $R C$ considers the event $\Delta V S$ to be central to calculating event-recharged water $V R$. However, it should be pointed out that the definition of $V R$ in the proposed method is quite different from that in the literature. The proposed method considers $V R$ of an event that discharges for infinite time, not during a fixed time interval. Some portion of the event's recharge is discharged during the event's peak in the measured hydrograph, but some portion, which is extrapolated, remains in the aquifer to supply the spring at later times.

Event and annual $R C$ s for the Sheshpeer karst catchment in Iran were calculated for nine isolated precipitation events and two hydrological years. Since most of the precipitation over the catchment is snow, calculated $R C$ s for hydrological years were more accurate and more in accord with former field studies. It was shown that the annual $R C s$ would be underestimated by over ten percent if the positive $\Delta V S$ during the study period was ignored.

In surface-water hydrology, groundwater recharge is estimated as an event-based process (e.g., Rutledge, 1998). Karst aquifers may contain well-developed conduit systems that are sometimes regarded as underground rivers (e.g., White and White, 1989), hence calculation of event-based $R C$ for karst catchments appears to be more reasonable than its calculation for fixed, short time intervals such as months. The latter would be especially unacceptable in arid and semi-arid regions, where the precipitation events are limited to certain periods, although permanent springs are discharging without any interruption.

\section{ACKNOWLEDGEMENTS}

The authors would like to acknowledge the Research Council of Shiraz University for their support. The helpful comments and suggestions of Dr. D. H. Doctor of the U.S. Geological Survey and the anonymous reviewers are gratefully acknowledged.

\section{REFERENCES}

Agha Amiri, S., 1993, Study on the geological structures in the karstic area of Gar and Barm-Firooz anticlines: [MSc thesis]: Shiraz, Iran, Shiraz University.

Alavi, M., 1994, Tectonics of the Zagros orogenic belt of Iran: new data and interpretations: Tectonophysics v. 229, p. 211-238. doi: 10.1016/ 0040-1951(94)90030-2.

Alavi, M., 2007, Structures of the Zagros fold-thrust belt in Iran: American Journal of Science, v. 307, p. 1064-1095. doi: 10.2475/09.2007.02.

Alijani, B., 2008, Effect of the Zagros Mountains on the spatial distribution of precipitation: Journal of Mountain Science, v. 5, no. 3, p. 218-231. doi: 10.1007/s11629-008-0126-8.

Allocca, V., Manna, F., and De Vita, P., 2014, Estimating annual groundwater recharge coefficient for karst aquifers of the southern Apennines (Italy): Hydrology and Earth System Sciences, v. 18, no. 2, p. 803-817. doi: 10. 5194/hess-18-803-2014.

Ashjari, J., and Raeisi, E., 2006, Influences of anticlinal structure on regional flow, Zagros, Iran: Journal of Cave and Karst studies, v. 68, no. 3, p. 118 129.

Azizi, M., 1992, Snow hydrology in a small catchment area, Barm-Firooz Mountain, [MSc thesis]: Shiraz, Iran, Shiraz University.

Baedke, S.J., and Krothe, N.C., 2001, Derivation of effective hydraulic parameters of a karst aquifer from discharge hydrograph analysis: Water resources research, v. 37, p. 13-19. doi: 10.1029/2000WR900247.

Bonacci, O., 1993, Karst springs hydrographs as indicators of karst aquifers: Hydrological Science, v. 38, no. 1, p. 51-62. doi: 10.1080/ 02626669309492639.

Bonacci, O., 2001, Monthly and annual effective infiltration coefficients in Dinaric karst: example of the Gradole karst spring catchment: Hydrological Sciences Journal, v. 46, no. 2, p. 287-299. doi: 10.1080/ 02626660109492822.

Bonacci, O., Jukić, D., and Ljubenkov, I., 2006, Definition of catchment area in karst: case of the rivers Krčić and Krka, Croatia: Hydrological Sciences Journal, v. 51, no. 4, p. 682-699. doi: 10.1623/hysj.51.4.682.

Burdon, D.J., and Papakis, N., 1963, Handbook of Karst Hydrogeology with Special Reference to the Carbonate Aquifers of the Mediterranean Region: Athens: Institute for Geology and Subsurface Research/FAO, $278 \mathrm{p}$.

Dewandel, B., Perrin, J., Ahmed, S., Aulong, S., Hrkal, Z., Lachassagne, P., Samad, M., and Massuel, S., 2010, Development of a tool for managing groundwater resources in semi-arid hard rock regions: application to a rural watershed in South India: Hydrological Processes, v. 24, no. 19, p. 2784-2797. doi: 10.1002/hyp.7696.

Doctor, D.H., 2008, Hydrologic connections and dynamics of water movement in the Classical Karst (Kras) aquifer: evidence from frequent chemical and stable isotope sampling: Acta Carsologica, vol. 37, no.1, p. $101-123$.

Doctor, D.H., and Alexander, E.C. Jr., 2005, Interpretation of water chemistry and stable isotope data from a karst aquifer according to flow regimes identified through hydrograph recession analysi, in Kuniansky, E.L., ed., U.S. Geological Suvey Karst Interest Group Proceedings, Rapid City, South Dakota, September 12-15, 2005: U.S. Geological Survey Scientific Investigations Report 2005-5160, p. 82-92.

Drogue, C., 1971, Coefficient d'infiltration ou infiltration eficace, sur le roches calcaires, in Actes du Colloque d'Hydrologie en Pays Calcaire, Besançon: Annales Scientifiques de l'Université de Besançon, Géologie, v. 15, p. 121-130. 
Ebadian, S., 2002, Assessment of controlling parameters on karstic groundwater potential of Gar and Barm-Firooz Anticlines in Fars Province, using digital satellite data and remote sensing, [MSc thesis]: Shiraz, Iran, Shiraz University.

Eftekhari, A., 1994, Hydrogeological characteristic of Sepidan karstic region using dye tracing, [MSc thesis]: Shiraz, Iran, Shiraz University.

Falcon, N.L., 1974, Southern Iran: Zagros Mountains, in Spencer, A.M., ed., Mesozoic Orogenic-Cenozoic Belts: Data for Orogenic Studies: Geological Society, London, Special Publications 4, p. 199-211. doi:10.1144/ GSL.SP.2005.004.01.11.

Fiorillo, F., 2011, Tank-reservoir drainage as a simulation of recession limb of karst spring hydrographs: Hydrogeology Journal, v. 19, p. 1009-1019. doi: 10.1007/s10040-011-0737-y.

Fiorillo, F., Pagnozzi, M., and Ventafridda, G., 2015, A model to simulate recharge processes of karst massifs: Hydrological Processes, v. 29, p. 2301-2314. doi: 10.1002/hyp.10353.

Ford, D.C., and Williams, P., 2007, Karst Hydrogeology and Geomorphology: John Wiley \& Sons, 576 p. doi: 10.1002/9781118684986.

Healy, R.W., and Cook, P.G., 2002, Using groundwater levels to estimate recharge: Hydrogeology Journal, v. 10, no. 1, p. 91-109. doi: 10.1007/ s10040-001-0178-0.

Horton, R.E., 1933, The role of infiltration in the hydrologic cycle: Eos, Transactions American Geophysical Union, v. 14, no. 1, p. 446-460. doi: 10.1029/TR014i001p00446.

James, G.A., and Wynd, J.G., 1965, Stratigraphic nomenclature of Iranian Oil Consortium Agreement area: AAPG Bulletin, v. 49, p. 2182-2245.

Jemcov, I., and Petric, M., 2009, Measured precipitation vs. effective infiltration and their influence on the assessment of karst systems based on results of the time series analysis: Journal of Hydrology, v. 379, no. 3-4, p. 304-314. doi: 10.1016/j.jhydrol.2009.10.016.

Jukić, D., and Denić-Jukić, V., 2004, A frequency domain approach to groundwater recharge estimation in karst: Journal of hydrology, v. 289, p. 95-110. doi: 10.1016/j.jhydrol.2003.11.005.

Jukić, D., and Denić-Jukić, V., 2009, Groundwater balance estimation in karst by using a conceptual rainfall-runoff model: Journal of Hydrology, v. 373, p. 302-315. doi: 10.1016/j.jhydrol.2009.04.035.

Karami, G., 1993, Relationship of physiochemical characteristics of recharged water with the karstic springs in Gar and Barm-Firooz anticline [M.S. Thesis in Persian]: Shiraz, Shiraz University, 349 p.

Kasaeyan, A., 1990, Morphology of Barm-Firooz sinkholes and its effect on the general flow direction, [BSc thesis]: Shiraz, Iran, Shiraz University.

Kavousi, A., 2008, Boundary between diffuse and conduit flow in karstic formations, [MSc thesis]: Shiraz, Iran, Shiraz University.

Kavousi, A., and Raeisi, E., 2015, Estimation of groundwater mean residence time in unconfined karst aquifers using recession curves: Journal of Cave and Karst Studies, v. 77, no. 2, p. 108-119. doi: 10.4311/2014ES0106.

Maillet, E., 1905, Essais d'Hydraulique souterraine et fluviale: Paris, Librairie Scientifique A. Hermann, $282 \mathrm{p}$.

Marandi, K., 1990, Morphology of Gar mountain sinkholes and its effect on the general flow direction, [BSc thesis]: Shiraz, Iran, Shiraz University.

Maréchal, J.C., Dewandel, B., Ahmed, S., Galeazzi, L., and Zaidi, F.K., 2006, Combined estimation of specific yield and natural recharge in a semi-arid groundwater basin with irrigated agriculture: Journal of Hydrology, v. 329, no. 1-2, p. 281-293. doi: 10.1016/j.jhydrol.2006.02.022.

Marquénez, J., Lastra, J., and García, P., 2003, Estimation models for precipitation in mountainous regions: the use of GIS and multivariate analysis: Journal of Hydrology: v. 270, no. 1-2, p. 1-11. doi: 10.1016/ S0022-1694(02)00110-5.

Martos-Rosillo, S., González-Ramón, A., Jiménez, P., Durán, J.J., Andreo, B., and Mancera-Molero, E., 2015, Synthesis of Groundwater Recharge of Carbonate Aquifers in the Betic Cordillera (Southern Spain), in Andreo, B., Carrasco, F., Durán, J.J., Jiménez, P., and LaMoreaux, J.W., eds., Hydrogeological and Environmental Investigations in Karst Systems, Berlin, Springer, p. 91-102. doi: 10.1007/978-3-642-17435-3_11.

Milanovic, P., 1976, Water regime in deep karst: Case study of Ombla Spring drainage area, in Yevjevich, V.M., ed., Karst Hydrology and Water Resources: Proceedings of the U.S.-Yugoslavian Symposium, Dubrovnik, June $2-7$, 1975, v. 1: Highlands Ranch, Colorado, Water Resources Publications, p. $165-186$.
Nakhei, M., 1993, Application of geoelectric method in exploration of groundwater in karst area, [MSc Thesis]: Shiraz, Iran, Shiraz University.

Naoum, S., and Tsanis, I.K., 2004, Orographic precipitation modeling with multiple linear regression: Journal of Hydrologic Engineering, v. 9, p. 79102. doi: 10.1061/(ASCE)1084-0699(2004)9:2(79).

Pezeshkpour, P., 1991, Hydrogeological and hydrochemical evaluation of Kuh-e Gar and Barm-Firooz springs [M.S. Thesis in Persian]: Shiraz, Shiraz University, $282 \mathrm{p}$.

Phillips, P.C.B., and Durlauf, S.N., 1986, Multiple time series regression with integrated processes: The Review of Economic Studies, v. 53, p. 473-495. doi: $10.2307 / 2297602$.

Porhemat, J., 1993, Evaluation of hydrological balance parameters in karstic highland catchment area: [MSc Thesis]: Shiraz, Iran, Shiraz University

Porhemat, J., and Raeisi, E., 2001, Evaluation of natural recharge in karstic aquifers by water budget method in highland regions, in Günay, G., Johnson, K.S., Ford, D., and Johnson, A. I., eds., Present State and Future Trends of Karst Studies, Proceedings of the International Symposium and Field Seminar, September 2000: Marmaris, Turkey, UNESCO Technical Documents in Hydrology 49, v. 2, p. 547-555.

Raeisi, E., 2008, Ground-water storage calculation in karst aquifers with alluvium or no-flow boundaries: Journal of Cave and Karst Studies, v. 70, p. $62-70$.

Raeisi, E., 2010, Case Study: Sheshpeer Spring, Iran, in Kresic, N., and Stevanovic, Z., eds., Groundwater Hydrology of Springs: Engineering, Theory, Management and Sustainability: Burlington, Butterworth-Heinemann, p. 516-525.

Raeisi, E., and Karami, G., 1996, The governing factors of the physicochemical characteristics of Sheshpeer karst springs, Iran: Carbonates and Evaporites, v. 11, p. 162-168. doi: 10.1007/BF03175634.

Raeisi, E., and Karami, G., 1997, Hydrochemographs of Berghan karst spring as indicators of aquifer characteristics: Journal of Cave and Karst Studies, v. 59 , p. $112-118$.

Raeisi, E., Pezeshkpour, P., and Moor, F., 1993, Characteristics of karst aquifers as indicated by temporal changes of the spring's physicochemical properties: Iranian Journal of Science and Technology, v. 17, p. 17-28.

Raeisi, E., Zare, M., and Eftekhari, A., 1999, Application of dye tracing for determining characteristics of Sheshpeer karst spring: Theoretical and Applied Karstology, v. 11, p. 109-118.

Rasmussen, W.C., and Andreasen, G.E., 1959, Hydrologic budget of the Beaverdam Creek Basin, Maryland: US Geological Survey Water-Supply Paper 1472, $106 \mathrm{p}$.

Rorabaugh, M.I., 1964, Estimating changes in bank storage and ground-water contribution to streamflow: International Association of Scientific Hydrology, v. 63, p. 432-441.

Rutledge, A.T., 1998, Computer programs for describing the recession of ground-water discharge and for estimating mean ground-water recharge and discharge from streamflow records-Update: USGS Water-Resources Investigations Report 98-4148, 43 p.

Sabziparvar, A.A., Movahedi, S., Asakereh, H., Maryanaji, Z., and Masoodian, S.A., 2015, Geographical factors affecting variability of precipitation regime in Iran: Theoretical and Applied Climatology, v. 120, no. 1-2, p. 367-376. doi: 10.1007/s00704-014-1174-3.

Soulios, G., 1984, Infiltration efficace dans le karst hellénique. Journal of hydrology, v. 75(1), p. 343-356. doi: 10.1016/0022-1694(84)90058-1.

Stöcklin, J., and Setudehnia, A., 1971, Stratigraphic lexicon of Iran: Part 1, Central, North, and East Iran: Geology Survey of Iran, report 18, 370 p.

Torbarov, K., 1976, Estimation of permeability and effective porosity in karst on the basis of recession curve analysis, in Yevjevich, V., ed., Karst Hydrology and Water Resources, v.1, Karst Hydrogeology: Colorado, Water Resources Publications, p. 121-135.

Um, Myoung-Jin, Yun, Hyeseon, Cho, Woncheol, and Heo, Jun-Haeng, 2010, Analysis of orographic precipitation on Jeju-island using regional frequency analysis and regression: Water Resources Management, v. 24, no. 7, p. 1461-1487. doi: 10.1007/s11269-009-9509-z.

White, W.B., 1988, Geomorphology and hydrology of karst terrains. New York, Oxford University Press, 464 p.

White, W.B., and White, E.L., 1989, Karst hydrology: concepts from the Mammoth Cave area. Springer Science \& Business Media. 